\title{
Interorganizational relationships in the Brazilian construction industry supply chain
}

\author{
Christiane Wagner Mainardes Krainer" ${ }^{\mathrm{a} *}$ Jefferson Augusto Krainer ${ }^{\mathrm{a**}}$, Cezar Augusto Romano ${ }^{\mathrm{a} * * *}$ \\ aUniversidade Tecnológica Federal do Paraná, Curitiba, PR, Brasil \\ *chriswmk70@gmail.com, **profjeffersonkra@gmail.com, ***romano.utfpr@gmail.com
}

\begin{abstract}
Paper aims: This paper identifies variables that differentiate the relationship between small and medium-sized construction companies and suppliers; and impact the integration of the supply chain of the construction sector with the aim of obtaining performance gains.
\end{abstract}

Originality: The data was collected through a questionnaire to two specific groups of business: small and medium-sized construction and suppliers.

Research method: Survey with a sample of 50 construction companies and 50 suppliers. Through the discriminant analysis it was possible to identify the variables related to the relationship between construction companies and suppliers which distinguish more both groups of business.

Main findings: The biggest points of divergence are: operational relationship, degree of commitment with the product cycle, expectation of compliance with the agreement and pressure for a rise in quality.

Implications for theory and practice: The researched companies are not committed with the performance of the supply chain in the sector.

\section{Keywords}

Buyer-supplier relationships. Supply management. Providers. Construction companies.

How to cite this article: Krainer, C. W. M., Krainer, J. A., \& Romano, C. A. (2018). Interorganizational relationships in the Brazilian construction industry supply chain. Production, 28, e20170075. https://doi.org/10.1590/0103-6513.20170075.

Received: Nov. 29, 2017; Accepted: May 8, 2018.

\section{Introduction}

The Brazilian Construction Industry, more specifically the buildings sub-sector, plays an important role in growth and development in the country. Mello \& Amorim (2009) point out that around 93\% of companies in the Brazilian construction sector are small or medium-sized, and of these, 73\% operate in the buildings segment.

However, the construction sector is traditionally behind the times regarding management when compared to other industries, and this includes traditional structures (social, cultural, and political) that revert to low productivity and weak performance (Meng, 2012; Jeong et al., 2013; Papadopoulos et al., 2016). In Brazil, the buildings subsector is characterized by the low efficiency in production, unsatisfactory quality, lack of desire for modifications, use of a low-skilled workforce and high turnover of staff (Mello \& Amorim, 2009).

The supply chain of the construction industry is characterized by fragmentation, complexity, heterogeneity, existence of unique projects, and by consisting of a system of multiple businesses linked commercially, of several products and variable technological processes, with the objective of fulfilling a venture (Azambuja \& 0'Brien, 2008).

Since the industry of the construction sector is fragmented, this generates efficiency problems, such as lack of coordination and integration between the many functional faces of the supply chain, due to the separation between the project and the construction of the venture (Xue et al., 2005; Azambuja \& 0'Brien, 2008). The supply 
chains of the sector are structured by adverse short-term relationships, fragmentation in project delivery, and composed by multidisciplinary members that tend to make decisions based on their own goals and value systems with little consideration towards full performance of the project (Ju et al., 2017).

Akintoye et al. (2000) stress that for the supply chain management sector to operate in its full potential, it is necessary to improve bonds with suppliers, subcontractors and specialists (internal integration). The improvement of the relationship, according to Meng (2012), will increase the performance, reducing costs of conflicts and increasing opportunities for collaborative work. The manner in which the processes of acquisition and integration of suppliers are managed is fundamental for the acquisition of positive results, rise of productivity and for reduction of unitary costs (Vrijhoef \& Koskela, 2000; Christopher, 2016).

It can be noticed that the management of the interorganizational relationship has a key role in the supply chain of the construction sector. However, companies in the sector have a history of slow comprehension and assimilation in regard to building relationships in the supply chain (Jeong et al., 2013). And this is due, mostly, to the fact that after a project is completed, the teams/individuals that worked on it usually disperse and dissociate from each other (Bemelmans et al., 2012; Ju et al., 2017). Furthermore, there is a lot of research and models of interorganizational relationship developed by other industries, such as the automotive and electronic, in which production is the result of repetitive processes in a controlled environment of the factory, yet these are, mostly, of limited use in the construction industry.

This article analyzes the construction company-supplier relationship with the goal of aiding identification and comprehension of the structures of this relation. Unlike other studies, this research considers the perception of two direct agents, representative of the Brazilian Construction Sector supply chain (buildings subsector): supply companies and the small and medium-sized construction companies.

In this way, research focused on the interorganizational relationship, such as this one, justify themselves through the necessity of improvement in the cooperation between businesses and the flow of raw materials in the productive process, with the objective of obtaining increase in productivity, propagate technology and reduce costs and waste.

Within this context, this research has the purpose of identifying variables that discriminate the interorganizational relationship between small and medium-sized construction companies and suppliers; and impact the integration of the supply chain of the construction sector with the aim of obtaining performance gains.

\section{Literature review}

The productive process in the industry of the construction sector takes into account the final product (property), usually unique, with a long cycle of existence and inconsistency in the use of resources (Azambuja \& 0'Brien, 2008). The production chain has a fragmented nature (Akintoye et al., 2000; Azambuja \& 0'Brien, 2008; lsatto et al., 2015). The manufacturing projects are complex and marked by participants with knowledge in diverse areas (Ju et al., 2017). The companies present weak organizational performance (Meng, 2012; Jeong et al., 2013; Othman et al., 2015; Ju et al., 2017; Xu \& Zhao, 2017), especially in terms of time, cost, and quality (Meng, 2012; Xu \& Zhao, 2017).

Vrijhoef \& Koskela (2000) stress that the supply chain of the construction industry is: (i) convergent: the supplies converge to the construction site; (ii) temporary: the organizations that are formed for the execution of the unique venture do not usually persist for the next venture and can assume a different shape than before; and (iii) make-to-order: each project creates a unique product with little repetition.

The implementation of the philosophy for supply chain management has been investigated as a strategic measure to improve organizational performance of the construction companies (Bondinuba et al., 2016). Integration and coordination of the supply chain is essential to successfully execute projects of construction, and achieve possible cost reduction, maintain margins, competitive advantage, on-time delivery and of better underlying value for the client, improvement in productivity, value creation, higher trust in long-term planning and better relationships between parties (Isatto et al., 2015; Papadopoulos et al., 2016; Xu, \& Zhao, 2017).

McDermotti \& Khalfan (2012), Papadopoulos et al. (2016), and Ju et al. (2017) report in their research that the construction sector supply chain is a network of several multidisciplinary companies that comprise many complex interfaces and performance issues due to lack of integration and coordination. The challenge facing the sector, already addressed by the cited authors, is to improve efficiency of the supply chain. Meng (2012) stresses that construction companies can boost performance with a better relationship between parties of the project.

According to Christopher (2016) in regard to various productive sectors, supply chain management with emphasis on relationships, trust, acknowledgement, and cooperation is essential for positive results, rise in 
productivity, efficiency and unit cost reduction. This also applies to construction sector companies that operate in a supply chain with several suppliers, commercialization and maintenance services.

To increase the efficiency of relationship management it is necessary to have coordination between construction companies and their main suppliers (Bemelmans et al., 2012; Othman et al., 2015; Bondinuba et al., 2016; Xu \& Zhao, 2017). The construction company-supplier relationship is essential (Bemelmans et al., 2012; Othman et al., 2015; Bondinuba et al., 2016), since supply of materials is a major factor in construction engineering, increasingly performing a more significant role towards good progress in the supply chain ( $\mathrm{Xu} \mathrm{\&}$ Zhao, 2017). In regard to the relationship between construction companies and suppliers, Jeong et al. (2013) identified critical issues, which are: variable delivery time, inconsistent levels of safety stock, and evaluation of impoverished suppliers as the main restrictions that hinder efficient performance of the supply chain. Thus, we present the following hypothesis:

$\mathrm{H} 1$ : There is a lack of integration and coordination upstream the supply chain of the construction sector.

Comprehension of possible mechanisms and structures of interorganizational relationships is of utmost importance for management of the construction sector supply chain, aiding in problem-solving, and gains in performance by being more effect in terms of cost than time or quality (Meng, 2012). The management of supply chain relations is becoming more strategic for organizations in the construction sector (Jeong et al., 2013). According to Meng (2012) the key indicators for an effective supply chain relationship in the construction sector are: mutual goals, gains and sharing of issues, trust, culture, coordinated work, communication, problem-solving, risk allocation, performance measurement and continuous improvement.

Partnership building is highlighted as a strategy to improve supply management. The partnership with the supplier, as a participant in the upstream operation, allows a continuous flow of goods and services without any interruptions in the productive process. Merli (1994) considers three operational relationship levels regarding the degree of development denominated by the author as comakership, or partnership relationship, in which actions are taken jointly:

- Class 111 (common supplier): negotiations established based on minimum quality specifications; safety stocks; pricing, short-term individual batches; and systematic supply inspections;

- Class II (integrated supplier or operational comakership): quality guaranteed and self-certified based on pre-established criteria; systematic improvement of quality and pricing of supplied products; automatic replenishment and no intermediate stock; price adjustment based on agreed criteria; frequent supply in small batches for "open" orders; long-term relationship and periodic review; overall responsibility for supplied products; lack of receipt inspection; and consulting and training of suppliers;

- Class 1 (comaker supplier or partner): global comarkership with characteristics of a partnership; class 11 operational activities; cooperation on projects for new products/technologies; investment pools in research and development and in technological achievement; and continuous exchange of information about processes and products.

According to Li et al. (2001) there are four partnership stages:

- Stage 1 (competitive): three partner companies (A, B, and C) are in contact with each other in a single point. They are not in search of compromise, and there is a high degree of confrontation, which can result in disputes and conflicts. The partnership exists solely to meet contract requirements. It is the most common case of partnerships in the construction sector;

- Stage 2 (guided for cooperation): there is more communication and interaction among parties due to the format shift of organizations to adapt to the enterprise. Even so, barriers continue impervious and inflexible;

- Stage 3 (integrated) communication and interaction are further intensified with exchange of knowledge and resources among partners;

- Stage 4 (strategic cooperation): a strategic alliance is formed, which promotes effective communication, exchange of knowledge, access to technology and to resources. A partnership is built based on trust and compromise.

In the construction sector the preferred purchasing procedure is based on the lowest price (Bemelmans et al., 2012; Bondinuba et al., 2016), thus an adverse relationship instead of a collaborative one when compared to most industrial sectors (Ju et al., 2017). Jeong et al. (2013) stress the need of an attitude and culture change in the sector in regard to purchasing procedures. In Brazil, Bandeira et al. (2009) have already pursued a case study from which they concluded that the construction company-supplier relationship is based on, mostly, a 
relation of dominance due to inherent factors of the sector, such as large bargaining power imposed by the construction companies. Culture, politics, dependency, and trust have significant influence in the quality of the relationship between buyers and suppliers of construction materials (Bondinuba et al., 2016). Thus, we propose:

$\mathrm{H} 2$ : The interorganizational relationship between construction companies and suppliers is asymmetrical.

Tuten \& Urban (2001) in a study on many industrial sectors, including the construction sector, identified the reasons that encourage companies to build partnerships: cost reduction, competitive gain, improvement in performance indicators, and raise in product quality. The critical factors for success of partnerships were identified by several authors, as presented in Table 1.

For a successful partnership, trust is the most mentioned factor by the authors (Table 1). Common goals, equity or equality, effective communication, engagement, performance assessment, integrated team, and long-term relationship are the other highlighted factors by related authors in Table 1.

Table 1. Critical success factors for supplier-builder partnership.

\begin{tabular}{|c|c|c|c|c|c|c|c|c|c|c|c|c|c|c|}
\hline Factors & 1 & 2 & 3 & 4 & 5 & 6 & 7 & 8 & 9 & 10 & 11 & 12 & 13 & Frequency \\
\hline Trust & $x$ & & $\mathrm{x}$ & $x$ & $\mathrm{x}$ & $x$ & $x$ & $x$ & $x$ & $x$ & $x$ & $x$ & $x$ & 12 \\
\hline Common Goals & $x$ & $x$ & $x$ & $x$ & $\mathrm{x}$ & $x$ & & $x$ & $x$ & $x$ & $\mathrm{x}$ & $\mathrm{x}$ & $x$ & 12 \\
\hline Equity or Equality & & $x$ & $x$ & $x$ & $x$ & & $x$ & $x$ & & $x$ & $x$ & & $x$ & 9 \\
\hline Performance assessment & & $x$ & $\mathrm{x}$ & $x$ & $x$ & $x$ & & $x$ & & $x$ & & $x$ & $x$ & 9 \\
\hline Effective Communication & & & $x$ & & & $x$ & $x$ & & $\mathrm{x}$ & $x$ & $x$ & $x$ & $x$ & 8 \\
\hline Engagement & $x$ & $x$ & $x$ & & & $x$ & $x$ & $x$ & & $x$ & $x$ & & & 8 \\
\hline Long-term Relationship & & $x$ & & & & $x$ & & & $x$ & & $x$ & $x$ & $x$ & 6 \\
\hline Integrated Team & & & & & & $x$ & $x$ & $\mathrm{x}$ & $x$ & & $\mathrm{x}$ & $\mathrm{x}$ & & 6 \\
\hline Resolution of Problems/ Conflicts & & $x$ & $\mathrm{x}$ & & $\mathrm{x}$ & & & $\mathrm{x}$ & & & $\mathrm{x}$ & & $x$ & 6 \\
\hline Win-Win Philosophy & $\mathrm{x}$ & & & & $\mathrm{x}$ & & & $\mathrm{x}$ & & & & & $x$ & 4 \\
\hline Shared Risk & & $x$ & & & & & & $\mathrm{x}$ & & & & & & 2 \\
\hline Rewards and Mutual Benefits & & & & & & & $x$ & & & & & & & 1 \\
\hline Investments/ Incentives & & & & & & & & & & & $x$ & & & 1 \\
\hline
\end{tabular}

(1) Cook \& Hancher (1990); (2) Bennett \& Jayes (1995); (3) Lenard et al. (1996); (4) Hellard (1995); (5) Matthews et al. (1996); (6) Black et al. (2000); (7) Scott (2001); (8) Kumaraswamy \& Dissanayaka (2001); (9) Cheng \& Li (2002); (10) Ng et al. (2002); (11) Tang et al. (2006); (12) Chen \& Chen (2007); (13) Yeung et al. (2007).

Santos \& Jungles (2008) reinforces the importance of the search for partners among the elements of the chain and that this should be a constant action in the businesses, due to the positive impact of competitiveness for both actors involved. The author points out three key factors for the formation of partnerships: trust and cooperation, long term relationships and sharing of information. When these three elements are present, the author stresses that the probability of a positive result, such as the increase on the level of added value and the reduction of waste, is higher.

Trust is based on the belief that the involved parties have an agreement to not act in opposition of the common interests (Neves \& Guerrini, 2010). Cooperation is essential in the processes of innovation, acquisition of technology and opening to different markets, since it allows access to completion of production, resources and products which lead to the reduction of risks and/or competitive advantages (Guerrini \& Vergna, 2011).

The long term relationship element also guarantees more trust. According to Bondinuba et al. (2016), construction companies and suppliers should focus on building trust as a foundation for long-term relationships.

The long relationship is usually established through contracts. The contracts, besides consolidating trust, allow a shared strategic view and a bigger collaboration between the businesses, since a good buyer will work beside his supplier and vice-versa for both to stay strong financially (Purdy \& Safayeni, 2000). Santos \& Jungles (2008) mentions that the long-term relationships permit the formation of a shared strategic view and are established through long-term contracts, with automatic renewals according to the achievement of the expected results. The nature of long-term is essential for successful results in the management of parties in an engineering project (Bemelmans et al., 2012).

The third key element for the formation of partnerships is sharing information, which can be since specifications of products and services, planning and programming of purchases, until full access to a database with information of clients and/or suppliers. This element catalyses interorganizational integration, as far as it can enable the transfer of know-how and the joint accomplishment of training and meetings between buyers and suppliers (Purdy \& Safayeni, 2000). 
A collaborative and trustworthy environment based on information sharing is necessary to build relationships in the supply chain (Meng, 2012; Das et al., 2015; Papadopoulos et al., 2016). There is a strong connection between trust, long-term relationships, and information sharing (Purdy \& Safayeni, 2000). These variables operate as key indicators for an efficient relationship in the supply chain (Meng, 2012; Das et al., 2015; Papadopoulos et al., 2016). Thus,

H3: There are relevant variables that discriminate more the relationship between construction companies and suppliers.

\section{Methodology}

To achieve the objective of this article, we took into account the perception of two actors of the construction industry supply chain: the suppliers and the construction companies. A study was conducted with 50 suppliers and 50 companies of the Brazilian civil construction industry, in the sub-sector of building.

The use of a non-probability sample was due to convenience, selecting accessible members (companies that responded to the request of the study) of the population. However, since in Brazil - as in the international scenario - the building sub-sector contains similar general characteristics, as indicated by Mello \& Amorim (2009), we considered that sampling due to convenience would not be biased in regard to the whole population. Therefore, the obtained results would be representative of the studied universe.

A questionnaire split into two parts was used as an instrument to collect data: (i) profile of the organization and the interviewee; (ii) identification of the elements that constitute the relationship between construction company and supplier (Table 2). The utilized variables for creating the data collection instrument are especially related to trust and coordination, long-term relationships, and information sharing as stressed by authors such as Santos \& Jungles (2008), Bandeira et al. (2009), Meng (2012), Jeong et al. (2013) and some present in Table 1.

Table 2. Applied questionnaire - variables V1 to V20.

\begin{tabular}{|c|c|c|c|}
\hline $\mathrm{V}$ & Construction Company & Supplier & $\mathrm{R}$ \\
\hline 1 & $\begin{array}{l}\text { What is the degree of commitment of the supplier in the } \\
\text { participation and contribution in the cycle of development of } \\
\text { your own products? }\end{array}$ & $\begin{array}{l}\text { What is the degree of commitment of the company in } \\
\text { the participation and contribution towards the product } \\
\text { development cycle of your clients/construction companies? }\end{array}$ & $\begin{array}{l}1,2,3,6 \\
7,8\end{array}$ \\
\hline 2 & Is there an operational relationship with your suppliers? & $\begin{array}{l}\text { Is there an operational relationship with your clients/ } \\
\text { construction companies? }\end{array}$ & $\begin{array}{l}1,2,3,4 \\
5,6,7,8\end{array}$ \\
\hline 3 & $\begin{array}{l}\text { What is the level of trust of the company regarding the } \\
\text { suppliers? }\end{array}$ & $\begin{array}{l}\text { What is the level of trust of the company regarding the clients/ } \\
\text { construction companies? }\end{array}$ & $\begin{array}{l}1,2,3,4 \\
5,6,7,8\end{array}$ \\
\hline 4 & $\begin{array}{l}\text { What are your expectations that the suppliers will fulfill the } \\
\text { agreement? }\end{array}$ & $\begin{array}{l}\text { What are your expectations that the clients/construction } \\
\text { companies will fulfill the agreement? }\end{array}$ & 1,3 \\
\hline 5 & $\begin{array}{l}\text { ls the relationship between the company and the suppliers a } \\
\text { longstanding one? }\end{array}$ & $\begin{array}{l}\text { any and the clients/ } \\
\text { ing one? }\end{array}$ & $\begin{array}{l}1,2,3 \\
6,8\end{array}$ \\
\hline 6 & $\begin{array}{l}\text { Is the contract renewed automatically when the desired } \\
\text { performance and objective are met? }\end{array}$ & $\begin{array}{l}\text { cally when the desired } \\
\text { t? }\end{array}$ & 1,3 \\
\hline 7 & $\begin{array}{l}\text { Are there expectations of new contracts with your current } \\
\text { suppliers? }\end{array}$ & $\begin{array}{l}\text { Are there expectations of new contracts with your current } \\
\text { partners? }\end{array}$ & 3,4 \\
\hline $\mathrm{V}$ & Construction Company & Supplier & $\mathrm{R}$ \\
\hline 8 & $\begin{array}{l}\text { Do your suppliers encourage and invest in the development of } \\
\text { new technologies? }\end{array}$ & $\begin{array}{l}\text { artners encourage and invest in the development of } \\
\text { hologies? }\end{array}$ & $1,2,3$ \\
\hline 9 & $\begin{array}{l}\text { Do the suppliers have access to the composition of costs of } \\
\text { your products (ventures)? }\end{array}$ & $\begin{array}{l}\text { Do the clients have access to the composition of costs of your } \\
\text { products? }\end{array}$ & $1,3,4$ \\
\hline 10 & $\begin{array}{l}\text { Does the company pressure the suppliers so there is a rise in } \\
\text { quality? }\end{array}$ & $\begin{array}{l}\text { Does the company pressure the clients/construction companies } \\
\text { so there is a rise in quality? }\end{array}$ & $\begin{array}{l}1,2,3,4 \\
5,6,7,8\end{array}$ \\
\hline 11 & $\begin{array}{l}\text { How does the company perceive itself regarding its bargaining } \\
\text { power towards its suppliers? }\end{array}$ & $\begin{array}{l}\text { How does the company perceive itself regarding its bargaining } \\
\text { power towards its clients (buyers)? }\end{array}$ & $1,4,6,8$ \\
\hline 12 & $\begin{array}{l}\text { Does the supplier offer its differentiated pricing policy to your } \\
\text { company? }\end{array}$ & $\begin{array}{l}\text { E 1s there a differentiated pricing policy for clients/ } \\
\text { construction companies that maintain a partnership with the } \\
\text { company? }\end{array}$ & $1,2,6,8$ \\
\hline 13 & Do your suppliers interfere in the production programs? & Do your partners interfere in the production programs? & $2,3,6$ \\
\hline 14 & $\begin{array}{l}\text { Does the company have exclusive supply deals on your } \\
\text { ventures? }\end{array}$ & $\begin{array}{l}\text { Does the company have exclusive supply deals on the ventures } \\
\text { of its clients/construction companies? }\end{array}$ & $\begin{array}{l}2,5,6 \\
7,8\end{array}$ \\
\hline 15 & $\begin{array}{l}\text { Does the company have suppliers that represent } 50 \% \text { or more } \\
\text { of the costs of supply to the company? }\end{array}$ & $\begin{array}{l}\text { Does the company have partners that represent } 50 \% \text { or more } \\
\text { of the profit of the company? }\end{array}$ & 2,4 \\
\hline 16 & $\begin{array}{l}\text { Does the company demand certificates of quality on its } \\
\text { products and/or processes? }\end{array}$ & $\begin{array}{l}\text { Do your partners demand certificates of quality of your } \\
\text { company? }\end{array}$ & 5 \\
\hline
\end{tabular}

R: (1) Santos \& Jungles (2008); (2) Bandeira et al. (2009); (3) Meng (2012); (4) Jeong et al. (2013); (5) Scott (2001); (6) Kumaraswamy \& Dissanayaka (2001); (7) Ng et al. (2002); (8) Yeung et al. (2007). 
Table 2. Continued...

\begin{tabular}{|c|c|c|c|}
\hline $\mathrm{V}$ & Construction Company & Supplier & $\mathrm{R}$ \\
\hline 17 & $\begin{array}{l}\text { Do the suppliers have autonomy to deliver materials without } \\
\text { orders? }\end{array}$ & $\begin{array}{l}\text { Does the company have autonomy to deliver materials without } \\
\text { orders? }\end{array}$ & $3,4,6$ \\
\hline 18 & $\begin{array}{l}\text { Does the supplier participate in the meetings with the technical } \\
\text { staff and the supply sector of the company? }\end{array}$ & $\begin{array}{l}\text { Does the company participate in the meetings with the } \\
\text { technical staff and the supply sector of the client/construction } \\
\text { company? }\end{array}$ & $\begin{array}{c}1,2,3 \\
7,8\end{array}$ \\
\hline 19 & $\begin{array}{l}\text { Does the company carry out recruitment processes for } \\
\text { choosing its suppliers? }\end{array}$ & $\begin{array}{l}\text { Does the company participate in recruitment processes carried } \\
\text { out by its clients/construction companies? }\end{array}$ & $2,4,6,7$ \\
\hline 20 & $\begin{array}{l}\text { Does the company carry out an evaluation process to measure } \\
\text { the performance of its suppliers (inputs)? }\end{array}$ & $\begin{array}{l}\text { Does the client/construction company evaluate the } \\
\text { performance of the company? }\end{array}$ & $\begin{array}{l}2,4,6 \\
7,8\end{array}$ \\
\hline
\end{tabular}

R: (1) Santos \& Jungles (2008); (2) Bandeira et al. (2009); (3) Meng (2012); (4) Jeong et al. (2013); (5) Scott (2001); (6) Kumaraswamy \& Dissanayaka (2001); (7) Ng et al. (2002); (8) Yeung et al. (2007).

To transform the qualitative variables into quantitative ones a semantic differential scale that comprehends a pair of adjectives and antonym sentences was used. The respondents distributed the answers on an intensity scale from 1 to 7 points. Table 3 demonstrates an example of how the issue of the semantic differential scale was considered in the questionnaire applied for this study.

Table 3. Example of a semantic differential scale.

\begin{tabular}{lllllllll}
\hline Slightly committed & 1 & 2 & 3 & 4 & 5 & 6 & 7 & Yes, strongly committed \\
No relationship & 1 & 2 & 3 & 4 & 5 & 6 & 7 & Intense relationship \\
Low confidence & 1 & 2 & 3 & 4 & 5 & 6 & 7 & High confidence \\
\hline
\end{tabular}

The collected data was analyzed with the use of descriptive and inferential statistics (discriminant analysis). The tool of choice was the Statistical Package for the Social Sciences (SPSS).

The descriptive statistics were utilized to describe and summarize the data by the following measures: median, coefficient of variation, and sum of responses. The median indicates the qualitative level of satisfaction in the construction company-supplier relationship; the higher this value, the better the relationship. The sum of responses reveals the overall measure of the construction company-supplier relationship, whereas the coefficient of variation indicates what is the relative position of the standard deviation compared to the average.

The discriminant analysis had the goal of identifying variables associated with the interorganizational relationship that diverge in the relationship between construction companies and suppliers. The management research identified as a dependent variable to be a construction company (D1) or a supplier (D2).

The first assessment, in the discriminant analysis, affirms the existence of distinction between the averages of the independent variables. The objective is to test the hypothesis that the averages of the samples are equal, a null hypothesis (Ho).

The next test, Box's M, has the objective of identifying the equality in the matrixes of variance and covariance. The equality of the matrixes finds support if the $p$-value (sig.) is bigger than the level of significance $(\alpha)$ of 0.05 . If the value is lower the assumption is violated.

Continuing the analysis, the hypothesis test of Wilk's Lambda evaluates if the discriminant function observes a difference between the two groups. The objective is to reject the hypothesis that the population average of both groups is the same. The test seeks to eliminate $\mathrm{HO}$ (the population average of both groups is the same) so that the averages become significantly different in order to discriminate the groups more effectively. For HO to be rejected, the $p$-value (sig.) must comply with $\alpha<0.05$, thus it can be concluded that it is significant.

In order to draw comparisons between construction companies and suppliers, the medians of variables that discriminate relationships between groups were compared. A maneuver chart of 9 vertices was designed to visualize results, each one representative of a discriminant variable.

\section{Results}

In this section, the data analysis and the obtained results are presented. In subsection 4.1 the sample is identified. In subsections 4.2 and 4.3 the descriptive analysis and discriminant analysis are presented, respectively. In subsection 4.4 the results are summarized.

\subsection{Identification of the sample}

Firstly, the sample (researched businesses and interviewed persons) was identified. The sample contained 50 construction companies and 50 suppliers of the construction industry. 
Most of the researched companies are located in Curitiba (64\% of construction companies and 46\% of suppliers); have operated for more than five years ( $82 \%$ and $86 \%)$; and are limited partnerships (76\% and 70\%). It is also noticeable that the construction companies are managed by family members (38\%), as well as through professionals (40\%) and the suppliers are managed mostly by professionals (58\%); the construction companies have a maximum of 19 employees and the suppliers (32\%) have from 20 till 99 employees; 54\% of the construction companies do not have any certification and the suppliers hold ISO $9001(28 \%)$ or no certification (58\%).

It must be stressed that, according to the classification by the Brazilian Service of Support for Micro and Small Enterprises, the researched companies (with up to 19 employees) are considered Small and Medium-sized enterprises (SMEs). Furthermore, these construction companies have a Gross Operating lncome lower than $\mathrm{R} \$$ 90.000.000,00 (classified as SMEs for obtention of funding by the Brazilian Development Bank, known as the National Bank for Economic and Social Development - BNDES).

Regarding the interviewed professionals, most belong to a department of engineering (50\% in the construction companies) or sales (44\% in the suppliers). It is important to clarify that the vendors of the suppliers are skilled workers, mostly engineers or managers of the company.

\subsection{Descriptive analysis}

The first analysis was of a data set through descriptive statistics, as summarized in Table 4. It is important to emphasize that the descriptive measures work as a visualization of the efficiency of the relationship between construction companies and suppliers.

Table 4. Descriptive statistics.

\begin{tabular}{|c|c|c|c|c|c|c|c|c|}
\hline \multirow[b]{2}{*}{ V } & \multicolumn{4}{|c|}{ Construction Company } & \multicolumn{4}{|c|}{ Supplier } \\
\hline & Mean & Mode & Median & $\begin{array}{l}\text { Standard } \\
\text { Deviation }\end{array}$ & Mean & Mode & Median & $\begin{array}{l}\text { Standard } \\
\text { Deviation }\end{array}$ \\
\hline 1 & 4.76 & 5 & 5 & 1.41 & 6.10 & 7 & 6.5 & 1.23 \\
\hline 2 & 3.54 & 3 & 3.5 & 1.54 & 5.34 & 7 & 6 & 1.57 \\
\hline 3 & 5.72 & 6 & 6 & 0.83 & 6.36 & 7 & 7 & 0.85 \\
\hline 4 & 5.88 & 6 & 6 & 0.96 & 6.52 & 7 & 7 & 0.89 \\
\hline 5 & 5.66 & 6 & 6 & 1.26 & 6.28 & 7 & 7 & 0.96 \\
\hline 6 & 4.22 & 6 & 5 & 2.19 & 4.62 & 7 & 5.5 & 2.49 \\
\hline 7 & 5.50 & 6 & 6 & 1.15 & 5.84 & 7 & 6 & 1.30 \\
\hline 8 & 4.70 & 5 & 5 & 1.45 & 4.90 & 6 & 5 & 1.58 \\
\hline 9 & 2.88 & 1 & 2.5 & 1.77 & 2.52 & 1 & 1 & 2.16 \\
\hline 10 & 5.30 & 6 & 6 & 1.54 & 3.72 & 1 & 3 & 2.08 \\
\hline 11 & 4.80 & 6 & 5 & 1.23 & 4.40 & 4 & 4 & 1.48 \\
\hline 12 & 5.16 & 6 & 5 & 1.09 & 6.06 & 7 & 7 & 1.41 \\
\hline 13 & 3.32 & 2 & 3 & 1.79 & 3.42 & 1 & 4 & 2.08 \\
\hline 14 & 2.84 & 1 & 2 & 2.06 & 2.76 & 1 & 2 & 2.22 \\
\hline 15 & 3.54 & 1 & 4 & 2.22 & 3.70 & 1 & 3.5 & 2.36 \\
\hline 16 & 4.74 & 5 & 5 & 1.59 & 4.42 & 7 & 5 & 2.04 \\
\hline 17 & 1.48 & 1 & 1 & 1.07 & 2.48 & 1 & 1 & 2.15 \\
\hline 18 & 3.18 & 1 & 3 & 1.83 & 4.04 & 5 & 4 & 1.86 \\
\hline 19 & 4.04 & 5 & 4 & 1.69 & 4.26 & 5 & 4 & 1.85 \\
\hline 20 & 4.46 & 6 & 5 & 1.74 & 4.80 & 5 & 5 & 1.74 \\
\hline
\end{tabular}

The suppliers do not perceive pressure to rise quality on the part of the construction companies (V10), there is no automatic replenishment without ordering (V17), and the construction companies denounce low operating relationship with their suppliers. Therefore, according to the typology of Merli (1994), the comakership level of the researched companies is not Class 11 (integrated supplier). Negotiations between construction companies and suppliers are established based on minimum quality specifications, pricing, short-term individual batches; and there are systematic inspections of supplies, hence, according to the classification of Merli (1994), the comakership level of the researched companies is Class 111 (common supplier).

Among the four partnership stages of $\mathrm{Li}$ et al. (2001), the researched companies do not adhere, in their majority, to stage 3 (integrated), but yes to stage 1 (competitive). There is no mutual access in regard to price 
formation of the products (V9), and there are few joint meetings (V18). On the other hand, the construction company-supplier relationships are sporadic, uncommitted and the partnership exists only to meet the requirements of the contract.

The results emphasize, therefore, lack of integration and coordination in the supply chain of the researched companies, as identified in the samples of McDermotti \& Khalfan (2012), Papadopoulos et al. (2016), and Ju et al. (2017). The H1 hypothesis is sustained.

Figure 1 demonstrates the distributions between the sum of the answers and the coefficient of variation, in other words, the relative positioning of construction companies and suppliers versus the global positioning in the construction company-supplier relationship. It can be observed that in regard to the total sum of answers (ordinate axis), the suppliers normally provide higher grades to the relationship with construction companies than the latter provides to their suppliers (a significant difference of 5\%), demonstrating an asymmetrical relationship.

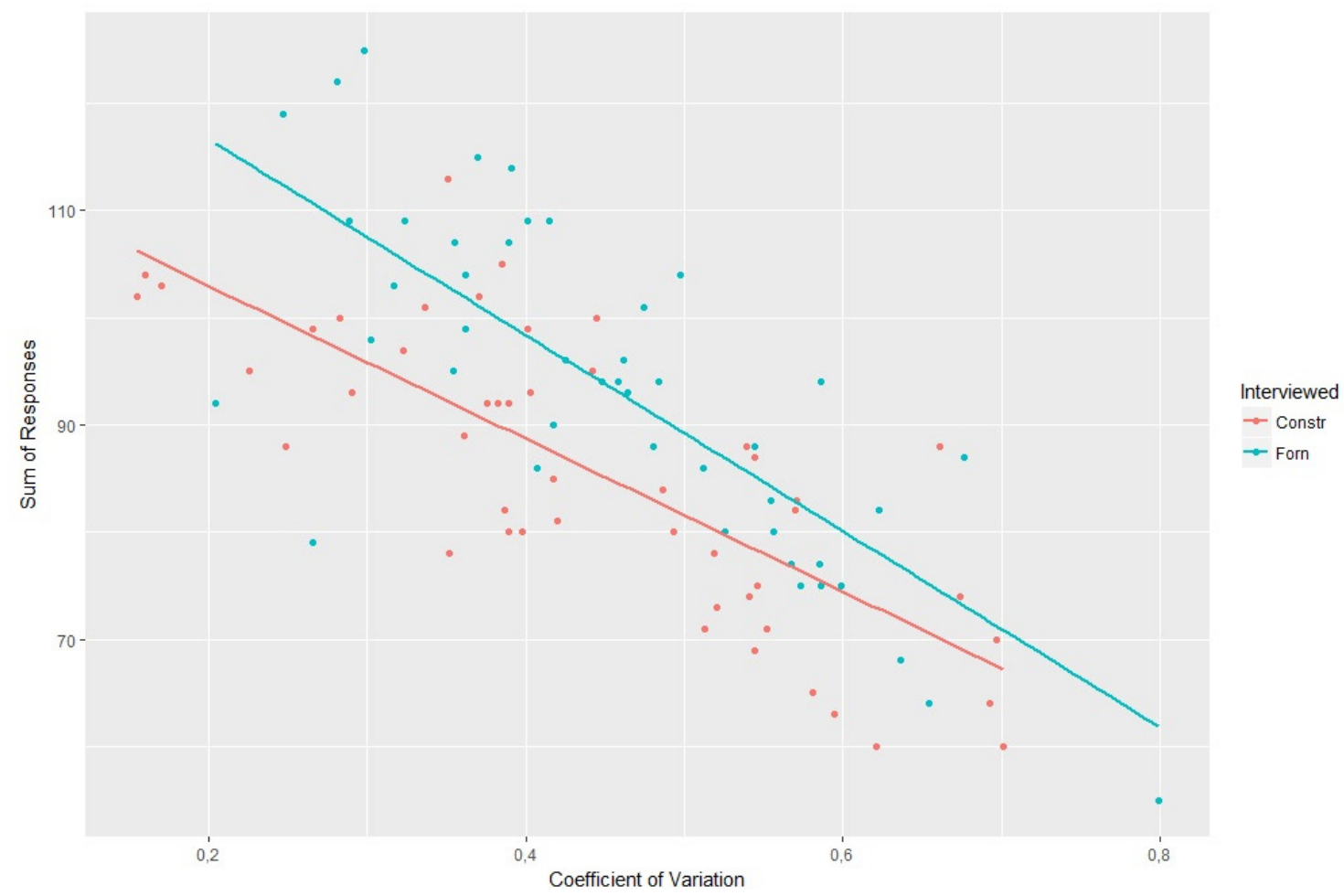

Figure 1. Position of builders and suppliers.

The results sustain hypothesis $\mathrm{H} 2$ and repeat and ratify the conclusions obtained in the studies of Bandeira et al. (2009), Jeong et al. (2013), and Ju et al. (2017).

\subsection{Discriminant analysis}

The first assessment of the discriminant analysis was the test for equality in the averages of the groups (D1 and D2) which present variables that passed on the assumption of equality of the matrixes of variance and covariance. The obtained result reinforces the significance of differentiation between the groups in the variables $\mathrm{V} 1, \mathrm{~V} 2, \mathrm{~V} 3, \mathrm{~V} 4, \mathrm{~V} 5, \mathrm{~V} 10, \mathrm{~V} 12$, V17 e V18, rejects the null hypothesis (H0), presenting p-value (sig.) lower than $\alpha$ of 0.05 , that is, the groups present characteristics of the organizational relationship that differentiate the relationships between construction companies and suppliers (Table 5).

The tests applied below are: (a) Box's M: to reject the hypothesis that the matrices are homogeneous; (b) Eigenvalue: to identify the level of association between the determinant scores and those of the groups, applying the obtained result with the percentage of the dependent variable exposed by the model; and (c) Wilk's Lambda: to denote the statistical significance of the discriminatory power of the discriminant functions. 
Table 5. Tests of equality of group means - D1 e D2.

\begin{tabular}{|c|c|c|c|c|c|c|c|c|c|c|c|}
\hline V & $\begin{array}{l}\text { Wilks' } \\
\text { Lambda }\end{array}$ & $\mathrm{F}$ & df1 & df2 & Sig. & V & $\begin{array}{l}\text { Wilks' } \\
\text { Lambda }\end{array}$ & $\mathrm{F}$ & df1 & df2 & Sig. \\
\hline V1 & 0.795 & 23.960 & 1 & 93 & 0.000 & V11 & 0.974 & 2.448 & 1 & 93 & 0.121 \\
\hline $\mathrm{V} 2$ & 0.776 & 26.865 & 1 & 93 & 0.000 & V12 & 0.898 & 10.599 & 1 & 93 & 0.002 \\
\hline V3 & 0.873 & 13.534 & 1 & 93 & 0.000 & V13 & 0.995 & 0.446 & 1 & 93 & 0.506 \\
\hline V4 & 0.847 & 16.772 & 1 & 93 & 0.000 & V14 & 1.000 & 0.002 & 1 & 93 & 0.964 \\
\hline V5 & 0.916 & 8.567 & 1 & 93 & 0.004 & V15 & 0.999 & 0.134 & 1 & 93 & 0.715 \\
\hline V6 & 0.987 & 1.262 & 1 & 93 & 0.264 & V16 & 1.000 & 0.011 & 1 & 93 & 0.915 \\
\hline V7 & 0.984 & 1.559 & 1 & 93 & 0.215 & V17 & 0.916 & 8.501 & 1 & 93 & 0.004 \\
\hline V8 & 0.999 & 0.047 & 1 & 93 & 0.829 & V18 & 0.948 & 5.090 & 1 & 93 & 0.026 \\
\hline V9 & 0.990 & 0.935 & 1 & 93 & 0.336 & V19 & 0.990 & 0.900 & 1 & 93 & 0.345 \\
\hline V10 & 0.861 & 15.004 & 1 & 93 & 0.000 & V20 & 0.976 & 2.307 & 1 & 93 & 0.132 \\
\hline
\end{tabular}

Table 6 presente the Box's M, Eigenvaleus, and Wilk's Lambda tests. The Box's M test presents a level of significance lower than 0.05 , thus the variables have a distinctive behavior and do not have to be eliminated or grouped. The Eigenvalue, obtained through the calculation of $R^{2} \mathrm{c}=(0.766)^{2}=0.59$, counts $59 \%$, which means that the variables chosen in the research are representative of the distinction between the groups. In the analysis of Wilk's Lambda, the first function, the significance is lower than 0.05 , thus the difference between the groups is significant.

Table 6. Box’s M, Eigenvaleus, and Wilk's Lambda tests.

\begin{tabular}{|c|c|c|c|c|c|c|}
\hline \multicolumn{2}{|c|}{ Box's M } & \multicolumn{5}{|c|}{ Eigenvalues } \\
\hline Test Result & 363.081 & Function & Eigenvalue & $\%$ of Variance & Cumulative \% & $\begin{array}{c}\text { Canonical } \\
\text { Correlation }\end{array}$ \\
\hline \multirow{3}{*}{$\begin{array}{l}\text { Approx. } \\
\text { df1 }\end{array}$} & 1.333 & 1 & $1.423^{\mathrm{a}}$ & 100.0 & 100.0 & 0.766 \\
\hline & 210 & \multicolumn{5}{|c|}{ Wilks' Lamba } \\
\hline & 25831.29 & $\begin{array}{c}\text { Test of } \\
\text { Function(s) }\end{array}$ & Wilks' Lambda & Chi-square & $\mathrm{df}$ & Sig. \\
\hline Sig. & 0.001 & 1 & 0.13 & 73.465 & 20 & 0.000 \\
\hline
\end{tabular}

aFirst 1 canonical discriminant functions were used in the analysis.

Table 7 shows a structural matrix that reveals the order of magnitude of the simple correlation between the functions and the discriminant variables ( $\mathrm{V} 2, \mathrm{~V} 1, \mathrm{~V} 4, \mathrm{~V} 10, \mathrm{~V} 3, \mathrm{~V} 12, \mathrm{~V} 5, \mathrm{~V} 17, \mathrm{~V} 18)$. This matrix highlights the variables that truly discriminate the sample.

Table 7. Structure Matrix.

\begin{tabular}{|c|c|c|c|c|}
\hline \multirow{2}{*}{$\mathrm{v}$} & \multirow{2}{*}{ Variable description } & Function & \multirow{2}{*}{$\mathrm{v}$} & \multirow{2}{*}{$\begin{array}{c}\text { Function } \\
1\end{array}$} \\
\hline & & 1 & & \\
\hline $\mathrm{V} 2$ & Operational Relationship & 0.451 & V20 & 0.132 \\
\hline $\mathrm{V} 1$ & Degree of commitment with the product cycle & 0.425 & V7 & 0.109 \\
\hline V4 & Compliance with the agreement & 0.356 & V6 & 0.098 \\
\hline V10 & Pressure for increase in quality & -0.337 & V9 & -0.084 \\
\hline V3 & Trust level & 0.320 & V19 & 0.082 \\
\hline V12 & Differentiated pricing policy & 0.283 & V13 & 0.058 \\
\hline V5 & Long-term relationship & 0.254 & V15 & 0.032 \\
\hline V17 & Autonomy to deliver without ordering & 0.253 & V8 & 0.019 \\
\hline V18 & Participation in meetings & 0.196 & V16 & -0.009 \\
\hline V11 & & -0.136 & V14 & 0.004 \\
\hline
\end{tabular}

The evaluation of the results obtained in the discriminant analysis is presented on Table 8 . It is noticeable that $90.5 \%$ of the cases were correctly classified. This means that if only the value of the variables were used, it would be possible to define the following relationships construction company $\mathrm{x}$ supplier and supplier $\mathrm{x}$ construction company in $90.5 \%$ of cases.

Figure 2 shows a maneuver chart of the variables that discriminate the relationship between builders and suppliers based on their medians (Table 4). 
Table 8. Classification results".

\begin{tabular}{cccccc} 
& \multirow{2}{*}{ V21 } & & \multicolumn{2}{c}{ Predicted Group Membership } & \multirow{2}{*}{ Total } \\
\cline { 3 - 5 } & & 1 & 1 & 2 & 50 \\
Original & \multirow{3}{*}{ Count } & 2 & 45 & 41 & 45 \\
& & 1 & 90.0 & 10.0 & 100.0 \\
& \multirow{2}{*}{$\%$} & 2 & 8.9 & 91.1 & 100.0 \\
\hline
\end{tabular}

${ }^{a} 90.5 \%$ of the grouped original cases were correctly classified.

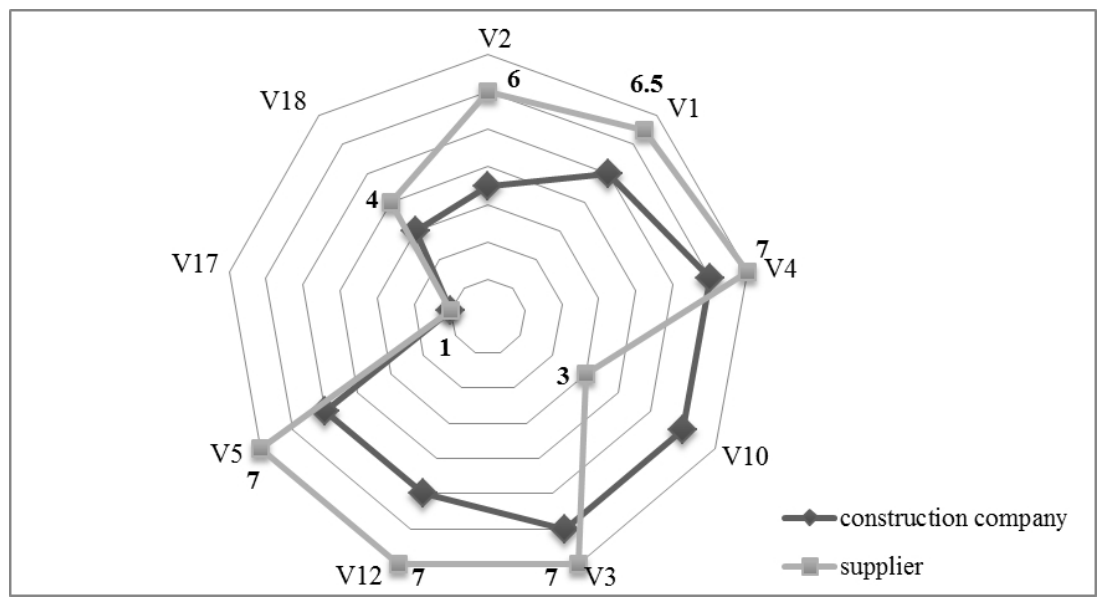

Figure 2. Maneuver chart - discriminant variables (construction companies and suppliers).

The discriminant variables, with the exception of pressure for increase in quality (V10) and autonomy to deliver without ordering (V17), are perceived by the suppliers more intensely when compared to the perception of the construction companies, which reinforces the conclusion that the relationship between both (construction companies and suppliers) is asymmetrical, restating $\mathrm{H} 2$.

The variable that discriminates most the relationship between construction companies and suppliers is the operational relationship (V2), followed by degree of commitment with the product cycle (V1). Construction companies and suppliers also differ in factors of trust and cooperation (variables V4, V10, V3, V12 e V17). Therefore, there are relevant variables that discriminate more the relationship between construction companies and suppliers, and $\mathrm{H} 3$ is sustained.

\subsection{Summary of results}

It was discovered that the three hypotheses are sustained, indicating broadly that there are relevant variables that discriminate the relationship between construction companies and suppliers.

The biggest discrepancy among the respondents (discriminant variable of most relevance) pertains to the operating relationship (V2), followed by degree of commitment with product development (V1), expectation of compliance with the agreement (V4), pressure for quality (V10) and level of trust (V3). The construction companies do not identify the operating relationship, the commitment, contract compliance and quality that the suppliers assert to have/offer. In fact, the operating relationship between suppliers and construction companies presents, also, weaknesses in regard of the following aspects: autonomy to deliver materials without orders (V17), conclusion of exclusive contracts (V14), and access to production costs (V9).

The suppliers perceive the interorganizational relationship as more withstanding when compared to the perception held by the construction companies, a similar situation to the perception on the variables differentiated pricing policy (V12) and autonomy for delivery of materials without orders (V17). Another highlighted variable is the participation in meetings with the technical staff and/or the sector of supplies of the construction company. For suppliers, participation (although infrequent) is perceived more than compared to construction companies. Indeed, the discrimination in these variables (V12, V17, and V18) highlights also, ratifying $\mathrm{H} 1$, the lack of integration and coordination in the supply chain in accordance with the studies of Purdy \& Safayeni (2000) and Xu \& Zhao (2017). 
Furthermore, the level of trust (V3) and commitment (V1) on the part of the construction companies is lower when compared to the trust the supplier claims to have with their clients/ construction companies. Hence, the construction companies, less trusting, do not perceive the cooperation and involvement that the suppliers, more trusting, claim to have. Trust, besides being the most mentioned factor for the success of a partnership by researchers (Table 1), affects the quality of the relationship between construction companies and suppliers (Bondinuba et al., 2016).

As for long-term relationship (V5), the respondents indicate a lasting relationship, besides results that demonstrate dissatisfaction by the construction companies in regard to services and products offered by the suppliers. According to the suppliers, the relationships last more than 5 years (level 7 in the semantic scale), thus they are long-term relationships (V5). On the other hand, the relationship for most construction companies withstands, on average, for 4 years (level 5). This corresponds with the average term of a project. Bemelmans et al. (2012) stress that the nature of long-term is essential to obtain positive results in an engineering project. After all, long-term relationships consolidate trust, enable greater collaboration between organizations, allow automatic renewal of contracts, and guarantee full and effective execution of activities on the worksite (Purdy \& Safayeni, 2000; Santos \& Jungles, 2008).

In summary, especially in face of divergences shown by the parties, we infer that the relationship among them is: asymmetrical, of average duration (considering the term of the project), and not centered on cooperation, with little/insufficient information sharing. Thus, a few of the key indicators of an effective relationship suggested by Meng (2012), Das et al (2015), and Papadopoulos et al. (2016) are not present. The construction companies do not perceive the effort/commitment of the suppliers and demonstrate insatisfaction towards their offered products/services. The suppliers, in turn, mostly maintain a good commercial relationship without worrying with performance of the supply chain of their client/construction company. This, added to low information sharing foments a lack of coordination and integration in this chain. Therefore, it is a more adversarial than collaborative relationship, in accordance with the studies of Ju et al. (2017).

\section{Conclusion}

The objective of this study is to identify variables that discriminate the interorganizational relationship between small and medium-sized construction companies and suppliers, and affect integration in the supply chain of the construction sector. Nine discriminant variables were identified (Table 8) that function as critical points to be overcome in the pursuit of better results (performance gains). The variable that discriminates most and, therefore, deserves foremost attention is the operating relationship.

The results indicate that the researched small and medium-sized companies of the construction sector do not apply, or apply unsatisfactorily management strategies upstream the supply chain. Several results sustain this conclusion, the selection and evaluation processes do not favor the best suppliers, and they continue participating in competitive bidding processes of purchase transactions based on the lower price. The researched construction companies adopt a traditional management model, without considering sharing culture and holding a low number of meetings with the technical staff, supply sector, and suppliers, maintaining an adverse relationship instead of a collaborative one.

The responding suppliers portray the relationship more positively than their clients/construction companies. They evaluate better their own products and services and the interorganizational relationship as a whole. However, the construction companies do not have the same perception; they do not recognize the commitment and operating relationship that the suppliers claim to have. This proves conformation with the situation on the part of the suppliers. They are more inclined to serve the construction companies in a fundamentally commercial relationship (the current state) than to transmute to a more integrated and cooperative interorganizational relationship.

The obtained results also indicate that the researched companies are not committed with the performance of the supply chain in the sector. Both, construction companies and suppliers, overall, are not certified and also deviate in terms of quality of products/services and the degree of commitment with the product cycle.

As an initial measure and minimal prudence for the establishment of a less asymmetrical relationship, in the long-term, focused on cooperation and in information sharing, it is recommended that the parties adopt actions directed at strengthening the operating relationship between construction companies and suppliers. This includes analysis; development; and joint standardization of processes, full costs, and products; the paperwork (conclusion of contracts and procedural service orders); and the reinforcement of communications (internal and intercompany). Management tools such as strategic planning, mapping of processes and mediation systems also aid this task. 
Finally, the great potential for improvement in the management of the construction company-supplier relationship as identified in this study challenges for further research with the goal of creating mechanisms that consolidate trust, strengthen commitment and overcome obstacles to gain cooperation between agents of the supply chain of the construction sector.

\section{References}

Akintoye, A., Mclntosh, G., \& Fitzgerald, E. (2000). A survey of supply chain collaboration and management in the UK construction industry. European Journal of Purchasing \& Supply Management, 6(3), 159-168. http://dx.doi.org/10.1016/S0969-7012(00)00012-5.

Azambuja, M., \& O'Brien, W. J. (2008). Construction supply chain modeling: issues and perspectives. In W. J. 0' Brien, C. T. Formoso, R. Vrijhoef \& K. A. London (Eds.), Construction supply chain management: handbook (pp. 2-31). Boca Raton: CRC Press. http:// dx.doi.org/10.1201/9781420047462.sec1.

Bandeira, R. A. M., Mello, L. C. B. B., \& Maçada, A. C. G. (2009). Relacionamento interorganizacional na cadeia de suprimentos: um estudo de caso na indústria da construção civil. Produção, 19(2), 376-387. http://dx.doi.org/10.1590/S0103-65132009000200012.

Bemelmans, J., Voordijk, H., Vos, B., \& Buter, J. (2012). Assessing buyer-supplier relationship management: Multiple case-study in the Dutch construction industry. Journal of Construction Engineering and Management, 138(1), 163-176. http://dx.doi.org/10.1061/ (ASCE)C0.1943-7862.0000418.

Bennett, J., \& Jayes, S. (1995). Trusting the team: the best practice guide to partnering in construction. London: Thomas Telford.

Black, C., Akintoye, A., \& Fitzgerald, E. (2000). An analysis of success factors and benefits of partnering in construction. International Journal of Project Management, 18(6), 423-434. http://dx.doi.org/10.1016/S0263-7863(99)00046-0.

Bondinuba, F. K., Edwards, D. J., Nimako, S. G., Owusu-Manu, D., \& Conway, C. (2016). Antecedents of supplier relation quality in the Ghanaian construction supply chain. International Journal of Construction Supply Chain Management, 6(1), 1-18.

Chen, W. T., \& Chen, T. T. (2007). Critical success factors for construction partnering in Taiwan. International Journal of Project Management, 25(5), 475-484. http://dx.doi.org/10.1016/j.jproman.2006.12.003.

Cheng, E. W. L., \& Li, H. (2002). Construction partnering process and associated critical success factors: quantitative investigation. Journal of Management Engineering, 18(4), 194-202. http://dx.doi.org/10.1061/(ASCE)0742-597X(2002) 18:4(194).

Christopher, M. (2016). Logistics \& supply chain management (5th ed.). New York: Pearson Education.

Cook, E. L., \& Hancher, D. E. (1990). Partnering: contracting for the future. Journal of Management Engineering, 6(4), 431-446. http:// dx.doi.org/10.1061/(ASCE)9742-597X(1990)6:4(431).

Das, M., Cheng, J. C. P., \& Law, K. H. (2015). An ontology-based web service framework for construction supply chain collaboration and management. Engineering, Construction, and Architectural Management, 22(5), 551-572. http://dx.doi.org/10.1108/ECAM07-2014-0089.

Guerrini, F. M., \& Vergna, J. R. G. (2011). Um modelo de atores e recursos para redes de cooperação entre empresas em obras de edificações. Produção, 21(1), 14-26. http://dx.doi.org/10.1590/S0103-65132011005000009.

Hellard, R. B. (1995). Project partnering: principle and practice. London: Thomas Telford. http://dx.doi.org/10.1680/pppap.20436.

Isatto, E. L., Azambuja, M., \& Formoso, C. T. (2015). The role of commitments in the management of construction make-to-order supply chains. Journal of Management Engineering, 31(4), 04014053-10. http://dx.doi.org/10.1061/(ASCE)ME.1943-5479.0000253.

Jeong, J. G., Hastak, M., Syal, M., \& Hong, T. (2013). Framework of manufacturer and supplier relationship in the manufactured housing industry. Journal of Management Engineering, 29(4), 369-381. http://dx.doi.org/10.1061/(ASCE)ME.1943-5479.0000164.

Ju, Q., Ding, L., \& Skibniewski, J. M. (2017). Optimization strategies to eliminate interface conflicts in complex supply chains of construction projects. Journal of Civil Engineering and Management, 23(6), 712-726. http://dx.doi.org/10.3846/13923730.2016.1232305.

Kumaraswamy, M. M., \& Dissanayaka, S. M. (2001). Developing a decision support system for building project procurement. Building and Environment, 36(3), 337-349. http://dx.doi.org/10.1016/S0360-1323(00)00011-1.

Lenard, D. J., Bowen-James, A., Thompson, M., \& Anderson, L. (1996). Partnering: models for success. Adelaide: Construction Industry Institute.

Li, H., Cheng, E. W. L., Love, P. E. D., \& Irani, Z. (2001). Co-operative benchmarking: a tool for partnering excellence in construction. International Journal of Project Management, 19(3), 171-179. http://dx.doi.org/10.1016/S0263-7863(99)00033-2.

Matthews, J., Tyler, A., \& Thorpe, A. (1996). Pre-construction project partnering: developing the process. Engineering, Construction, and Architectural Management, 3(1-2), 117-131. http://dx.doi.org/10.1108/eb021026.

McDermotti, P., \& Khalfan, M. (2012). Achieving supply chain integration within construction industry. Construction Economics and Building, 6(2), 44-54. http://dx.doi.org/10.5130/ajceb.v6i2.2983.

Mello, L. C. B. B., \& Amorim, S. R. L. (2009). 0 subsetor de edificações da construção civil no Brasil: uma análise comparativa em relação à União Europeia e aos Estados Unidos. Production Journal, 19(2), 388-399. http://dx.doi.org/10.1590/S0103-65132009000200013.

Meng, X. (2012). The effect of relationship management on project performance in construction. International Journal of Project Management, 30(2), 188-198. http://dx.doi.org/10.1016/j.jproman.2011.04.002.

Merli, G. (1994). Comakership: a nova estratégia para os suprimentos. Rio de Janeiro: Qualitymark.

Neves, F. V. F., \& Guerrini, F. M. (2010). Modelo de requisitos e componentes técnicos para a formação e gerência de redes de cooperação entre empresas da construção civil. Gestão \& Produção, 1711), 195-206. http://dx.doi.org/10.1590/S0104-530X2010000100015.

Ng, S. T., Rose, T. M., Mak, M., \& Chen, S. E. (2002). Problematic issues associated with project partnering - the contractor perspective. International Journal of Project Management, 20(6), 437-449. http://dx.doi.org/10.1016/S0263-7863(01)00025-4.

Othman, A. A., Abd Rahman, S., Sundram, V. P. K., \& Bhatti, M. A. (2015). Modelling marketing resources, procurement process coordination and firm performance in the Malaysian building construction industry. Engineering, Construction, and Architectural Management, 22(6), 644-668. http://dx.doi.org/10.1108/ECAM-02-2014-0030. 
Papadopoulos, G. A., Zamer, N., Gayialis, S. P., \& Tatsiopoulos, 1. P. (2016). Supply chain improvement in construction industry. Universal Journal of Management, 4(10), 528-534. http://dx.doi.org/10.13189/ujm.2016.041002.

Purdy, L., \& Safayeni, F. (2000). Strategies for supplier evaluation: a framework for potential advantages and limitations. IEEE Transactions on Engineering Management, 474), 435-443. http://dx.doi.org/10.1109/17.895339.

Santos, A. P. L., \& Jungles, A. E. (2008). Como gerenciar as compras de materiais de construção civil. São Paulo: Pini Editora.

Scott, B. (2001). Partnering in Europe: incentive based alliancing for projects. London: Thomas Telford. http://dx.doi.org/10.1680/ pieibafp.29651.

Tang, W., Duffield, C. F., \& Young, D. M. (2006). Partnering mechanism in construction: an empirical study on the chinese construction industry. Journal of Construction Engineering and Management, 132(3), 217-229. http://dx.doi.org/10.1061/(ASCE)07339364(2006)132:3(217).

Tuten, T. L., \& Urban, D. J. (2001). An expanded model of business-to-business partnership formation and success. Industrial Marketing Management, 30(2), 149-164. http://dx.doi.org/10.1016/S0019-8501(00)00140-1.

Vrijhoef, R., \& Koskela, L. (2000). The four holes of supply chain management in construction. European Journal of Purchasing \& Supply Management, 6(3-4), 169-178. http://dx.doi.org/10.1016/S0969-7012(00)00013-7.

Xu, J., \& Zhao, S. (2017). Noncooperative game-based equilibrium strategy to address the conflict between a construction company and selected suppliers. Journal of Construction Engineering and Management, 143(8), 04017051-10. http://dx.doi.org/10.1061/ (ASCE)C0.1943-7862.0001329.

Xue, X., Li, X., Shen, Q., \& Wang, Y. (2005). An agent-based framework for supply chain coordination in construction. Automation in Construction, 14(3), 413-430. http://dx.doi.org/10.1016/j.autcon.2004.08.010.

Yeung, J. F., Chan, A. P., \& Chan, D. W. (2007). The definition of alliancing in construction as a Wittgenstein family-resemblance concept. International Journal of Project Management, 25(3), 219-231. http://dx.doi.org/10.1016/j.jproman.2006.10.003. 